ISSN: 1410-8917

Jurnal Kimia

Sains \&

Aplikasi

e-ISSN: 2597-9914
Jurnal Kimia Sains dan Aplikasi Journal of Scientific and Applied Chemistry

Journal homepage: http://ejournal.undip.ac.id/index.php/ksa

\title{
Potential Antibacterial Activity of Bioactive $\beta$-sitosterol from Root Bark of Rhizophora apiculata from Lampung Coastal
}

\author{
Rahmat Kurniawan $^{\mathrm{a}, 1, *}$, Tati Suhartati ${ }^{\mathrm{b}, 2}$, Yandri ${ }^{\mathrm{b}, 3}$, Desi Meriyanti ${ }^{\mathrm{b}, 4}$, Sukrasno $^{\mathrm{c}, 5}$ \\ ${ }^{a}$ Organic Chemistry, Science Department, Institute Technology of Sumatera, Lampung, Indonesia \\ ${ }^{\mathrm{b}}$ Department of Chemistry, Faculty of Sciences and Mathematics, University of Lampung, Lampung, Indonesia \\ ${ }^{\mathrm{c}}$ Center for Research and Innovation of Biological Materials and Natural Materials, Institute Technology of Sumatera, Lampung, \\ Indonesia \\ * corresponding author: $(1, *)$ rahmat.kurniawan@ki.itera.ac.id; (2) tati.suhartati@fmipa.unila.ac.id; (3) yandri@fmipa.unila.ac.id; \\ (4)desimeriyanti@gmail.com; (5) sukrasno@itera.ac.id
}

https://doi.org/10.14710/jksa.24.4.114-119

\begin{tabular}{l} 
Article Info \\
\hline Article history: \\
Received: $2^{\text {nd }}$ February 2021 \\
Revised: $26^{\text {th }}$ March 2021 \\
Accepted: $27^{\text {th }}$ March 2021 \\
Online: $30^{\text {th }}$ April 2021 \\
\hline
\end{tabular}

Keywords:

mangrove; $\beta$-sitosterol;

antibacterial; Lampung coastal

\begin{abstract}
$\beta$-sitosterol is an essential bioactive phytosterol naturally present in plant cell membranes. It has a coincident structure with animal cholesterol. This investigation reported isolation, structure analysis, and an antimicrobial assay of $\beta$-sitosterol from the root bark of Bakau Minyak (Rhizophora apiculata) from Lampung coastal. The isolation of $\beta$-sitosterol was carried out through maceration using methanol, separation by vacuum liquid chromatography (VLC), and purification by column chromatography (CC) using ethyl acetate/nhexane (2:8) as eluent. The structure of $\beta$-sitosterol was determined using spectroscopic analysis (UV-Vis, FT-IR, ${ }^{13} \mathrm{C}-\mathrm{NMR},{ }^{1} \mathrm{H}-\mathrm{NMR}, \mathrm{DEPT}$, and GC-MS). The pure $\beta$-sitosterol has $107.4 \mathrm{mg}$ of white needle crystalline compound, the compound melting point about $140.7-141.2^{\circ} \mathrm{C}$, the molecular mass confirmed by $\mathrm{m} / z$ 414, and UV absorption detected at $\lambda 203.9 \mathrm{~nm}$. The $\beta$-sitosterol antimicrobial bioactivity assay has shown potential activity to be developed as a lead compound against $E$. coli.
\end{abstract}

\section{Introduction}

$\beta$-sitosterol (stigmast-5-en-3 $\beta$-ol) is a bioactive secondary metabolite type phytosterol naturally found in plant cell membrane surfaces, providing a chemical structure similar to that of mammalian cholesterol [1]. This compound is commonly found in various higher plant parts such as seed, wood, and root bark [2]. Bioactivity of $\beta$-sitosterol has been widely reported that it has antibacterial activity [3], non-alcoholic fatty liver disease (NAFLD) protecting agent [4], analgesic [5], anticancer [6], immunomodulatory [7], lipid-lowering effect [8], hepatoprotective [9], antidiabetic [10], respiratory protecting effect [11], wound recovery effect [10], antioxidant [12] and anti-inflammatory [13]. $\beta-$ sitosterol is a potential micronutrient and has been confirmed by the Food and Drug Administration (FDA) to degrade blood cholesterol levels, reduce heart disease risk, and have no prominent side effects identified [14, 15].

Mangrove forests found in Indonesia's coastal areas exhibit habitats with high biodiversity of animals, plants, and microorganisms [11]. Mangroves have been reported to generate steroid, alkaloids, and terpenoids [16], which have biological benefits such as antidiabetic [17], antibacterial [18], anticancer [19], and antioxidant abilities [20, 21]. These bioactivity properties of mangroves have impressed pharmaceutical industry interest [22]. This plant has been used as traditional medicines to treat diarrhea and asthma [23], scabies treatment, and rheumatism [24]. R. apiculate or known as Bakau Minyak in Lampung (Figure 1), is common mangrove growing on the coastal zones of Lampung. This plant is hardy, tannin-rich, and has a high density, mainly used for construction and charcoal making [23]. 
Bakau Minyak has a high salt tolerance. These natural properties provide several bioactive compounds produced in response to environmental stresses. The root bark of Bakau Minyak, which part has direct interaction with seawater, is mainly reported containing tannins and steroids [25], indicating it has a potential source of $\beta$-sitosterol.

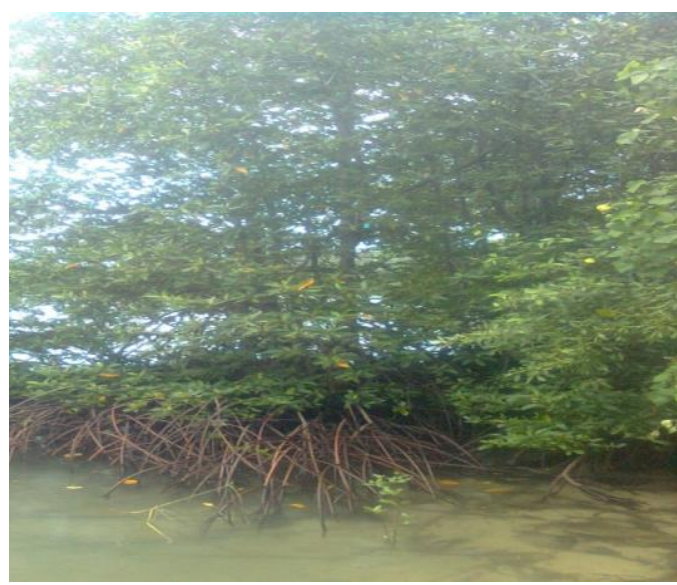

Figure 1. Bakau Minyak (R. apiculata) from Lempasing, South Lampung.

Although $R$. apiculata plays an essential role in traditional medicine in many tropical countries [11, 23], including Indonesia, only limited research has been scientifically reported to explore the bioactive and antimicrobial compound activity of this plant. Thus, the present study aims to investigate the antimicrobial activity of the bioactive $\beta$-sitosterol from the root bark of $R$. apiculata to increase the potential of mangrove forests on the Lampung coast. $\beta$-sitosterol was isolated using several chromatography techniques. Structural elucidation was carried out by spectroscopy analysis. The antimicrobial assay was determined by the agar diffusion method against Escherichia coli, Bacillus subtilis, and Aspergillus niger.

\section{Methodology}

The root bark of Bakau Minyak was obtained from the Research Center of Marine Development Cultivation (Balai Besar Pengembangan Budidaya Laut) Lempasing Coastal, Lampung, Indonesia. The specimen was determined as $R$. apiculata (Specimen number: IT IS.507389) by Botany Herbarium Bogoriensis in the Biology Research Center of The Indonesian Institute of Sciences (LIPI) Cibinong, West Java.

\subsection{Equipment/ Tool/ Material}

The chemicals used were ethyl acetate, methanol p.a. (Merck), n-hexane, acetone p.a. (Merck), 1.5\% cerium sulfate/sulfuric acid ( $2 \mathrm{~N}$ ), benzene p.a. (Sigma), chloroform p. a. (Merck), dichloromethane (Sigma), silica gel G 60 (Merck), silica gel 35-70 Mesh 60 (Merck), silica gel 60 F254 0.25 mm TLC plate (Merck), microbial medium growth: nutrient broth and nutrient agar (Supelco). Compound purification monitored using thinlayer chromatography was carried out on TLC plate $\mathrm{PF}_{254}$, and the spots were figured under ultraviolet light (254 and $366 \mathrm{~nm}$ ) and by exposure using cerium sulfate vapor. The methanol extracts were obtained by rotary evaporator HEI-VAP (Heidolph). The UV spectrum was obtained using UV-Vis (Shimadzu 1200). The melting point was measured using Melting Point Apparatus (Toledo HL3A). The $\beta$-sitosterol crystals were placed in a capillary glass tube, which was then inserted on the heating side. The crystals were heated until they melted, and the temperature was recorded. The IR spectra were obtained by FTIR spectroscopy (Scimitar 2100) using $\mathrm{KBr}$ pellets. The mass spectrum were acquired by GC-MS model QP2010 (Shimadzu) equipped with a VF5 column mass spectrometer (flow rate $1.8 \mathrm{~mL} / \mathrm{min}$ ) with diameter of $0.25 \mathrm{~mm}$, length of $30 \mathrm{~m}$, thickness of $0.25 \mu \mathrm{m}$ and under $200^{\circ} \mathrm{C}$ ion source $/-70 \mathrm{eV}$ at $40-650^{\circ} \mathrm{C}$ with a flow rate of $4{ }^{\circ} \mathrm{C} / \mathrm{min}$ (carrier gas was $\mathrm{He}$ ). ${ }^{13} \mathrm{C}$ and ${ }^{1} \mathrm{H} \mathrm{NMR}$ spectra were obtained by JEOL variant $500 \mathrm{MHz}$ spectroscopy in acetone- $\mathrm{d}_{6}$ and TMS as the zero-shift standards.

\subsection{Extraction and Isolation}

All extraction and isolation steps of $\beta$-sitosterol are shown in Figure 2. The dried powder of $R$. apiculata root bark ( $532 \mathrm{~g}$ ) was extracted with methanol $(4 \times 2 \mathrm{~L})$ under low pressure to obtain a final residue $(58.7 \mathrm{~g})$ of crude methanol extract (CME). The extraction occurred in about 72 hours with further removal of the solvent at a rotary evaporator at $50^{\circ} \mathrm{C} / 120 \mathrm{rpm}$. CME was partitioned in a solvent to present hexane (HE) (17.2 g) and ethanol $(21.4 \mathrm{~g})$ extracts (EE). This study focused on the HE fractions because the $\mathrm{EE}$ fraction has high tannin content, making it more difficult to eliminate the tannin tint in the separation process [25]. $15.5 \mathrm{~g} \mathrm{HE}$ was chromatographed using the vacuum liquid chromatography method, eluted using a gradient solvent by increasing the polarity of the eluent (hexane/ethyl acetate) to produce 33 fractions. The fractions 3, 4, and 5 were re-chromatographed using silica gel G-60 and eluted with hexane: ethyl acetate $(4: 1, \mathrm{v} / \mathrm{v})$. Among the 16 fractions obtained, fractions 3-9 were purified using a silica gel column to give a compound mixture (403.7 $\mathrm{mg}$ ). The fraction of $403.7 \mathrm{mg}$ was chromatographed on the silica gel column to produce 12 fractions. Fractions 4-9 yielded compound 1 (115.8 mg). After recrystallization in hexane, this fraction was identified as $\beta$-sitosterol (107.4 mg).

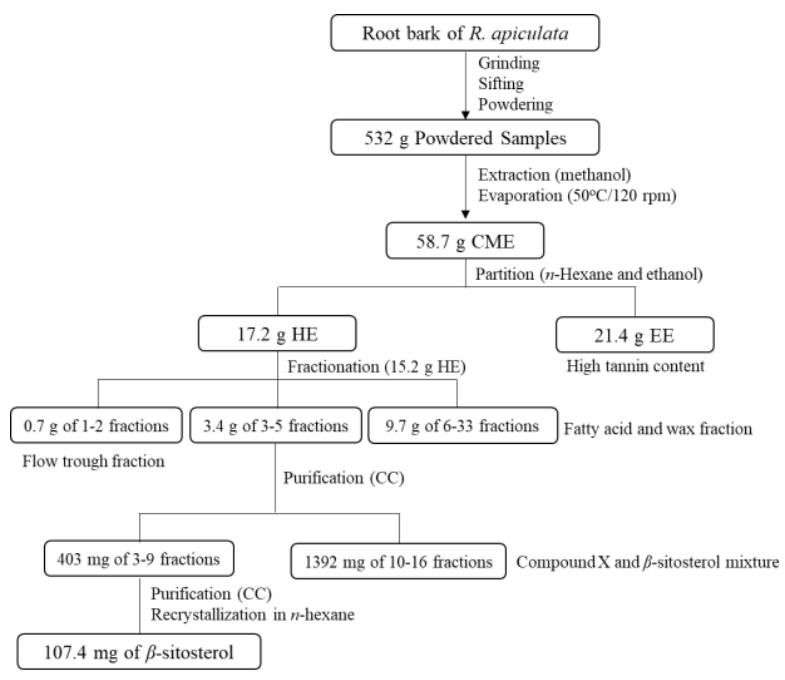

Figure 2. The flow chart of $\beta$-sitosterol isolation. 


\subsection{Antimicrobial Assay}

The fungal and bacterial strains were acquired from the microbiology laboratory of The Indonesian Institute of Sciences LIPI-Cibinong and Biochemistry laboratory of the Chemistry department, University of Lampung collections. The antimicrobial assay was determined against $E$. coli, B. subtilis, and $A$. niger by the agar diffusion method. Both fungi and bacterial were cultured in nutrient broth $(\mathrm{NB})$ medium with a conical flask serial, incubated at $37^{\circ} \mathrm{C} / 24 \mathrm{~h}$. Pre-warmed NB agar plates were seeded with $10^{7}-10^{8} \mathrm{CFU}$ suspension of bacteria and fungi. The paper discs ( $5 \mathrm{~mm}$ Whatman assay disc) were drilled into the wells plate, then the compound and the extract were slowly added until discs were filled. After all filled discs were placed in an upright position and then incubated at $37^{\circ} \mathrm{C}$ for $24 \mathrm{~h}$, the inhibition zones were measured in millimeters ( $\mathrm{mm}$ ). The antimicrobial assay protocol was carried out under aseptic conditions, based on a standard procedure adapted from Balouiri et al. [26] with some modification.

\section{Results and Discussion}

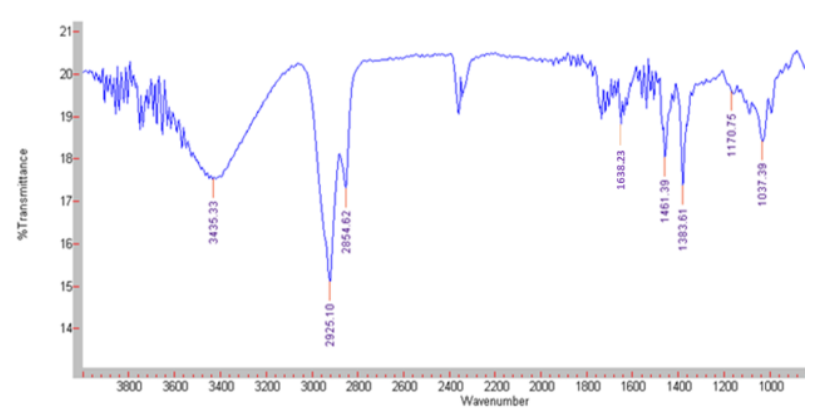

Figure 3. The IR spectrum of $\beta$-sitosterol

About $107.4 \mathrm{mg}$ of pure white needle crystalline compound was isolated with the melting point of 140.7$141.2^{\circ} \mathrm{C}$. The molecular mass was at $m / z 414$, confirmed by the GC-MS chromatogram, and the UV absorption peak was detected at $\lambda$ of $203.9 \mathrm{~nm}$ in methanol. Based on Figure 3, the FTIR spectrum exhibits the absorptions band $\left(\mathrm{cm}^{-1}\right)$ for stretching $\mathrm{O}-\mathrm{H}$ at $3435.33, \mathrm{CH}_{3}$ at 2925.10, $\mathrm{CH}_{2}$ at 2854.62, and both absorptions $\mathrm{C}-\mathrm{H}\left(\mathrm{sp}^{3}\right)$ stretching for asymmetrical and symmetrical, respectively. Non-conjugated olefinic $(\mathrm{C}=\mathrm{C})$ at 1638.23, methylene in non-aromatic cyclic groups $\left(\mathrm{CH}_{2}\right)_{\mathrm{n}}$ at $1461.39, \mathrm{C}-\mathrm{H}$ bending is for scissoring and rocking of the germinal dimethyl group at 1382.09 and $\mathrm{C}-\mathrm{OH}$ from secondary alcohol at 1037.39. The FTIR spectrum analysis has detected the nature of oxygen identified as a hydroxyl group. The FTIR spectrum also detects the existence of one $\mathrm{C}=\mathrm{C}$ in the structure. The FTIR data are summarized in Table 1.

The NMR spectrum (Figure. 4) exhibits the existence of fifty protons containing six methyl $\left(\mathrm{CH}_{3}\right)$, eleven methylene $\left(\mathrm{CH}_{2}\right)$, nine methines $(\mathrm{CH})$, and one hydroxy group. The presence of two singlets at $\delta 0.84$ and 0.83 ppm confirm the existence of two $\mathrm{CH}_{3}$ attached to the quaternary carbons. The appearance of two multiplet signals at $\delta 2.3 \mathrm{ppm}$ indicates that two methylene protons are adjacent to the carbon attached to the hydroxyl group. A proton signal at $\delta 3.52 \mathrm{ppm}$ in multiple properties presents a proton connected to the carbon, which is correlated with the $\mathrm{OH}$ groups. The overlapping triplets at $\delta 5.38 \mathrm{ppm}$ are assigned to the olefinic protons.

Table 1. The IR spectrum of $\beta$-sitosterol

\begin{tabular}{cc}
\hline Absorption band $\left(\mathrm{cm}^{-1}\right)$ & Functional Groups \\
\hline 3435.33 & $\mathrm{O}-\mathrm{H}$ stretching \\
2925.10 & $\mathrm{C}-\mathrm{H}\left(\mathrm{sp}^{3}\right)$ stretching \\
2854.62 & $\mathrm{C}-\mathrm{H}\left(\mathrm{sp}^{3}\right)$ stretching \\
1638.23 & $\mathrm{C}=\mathrm{C}$ (cyclic alkene) \\
& stretching \\
1461.39 & $\mathrm{C}-\mathrm{H}\left(\mathrm{CH}_{2}\right)$ bending \\
1383.09 & $\mathrm{O}-\mathrm{H}(\mathrm{C}-\mathrm{OH})$ bending \\
\hline
\end{tabular}

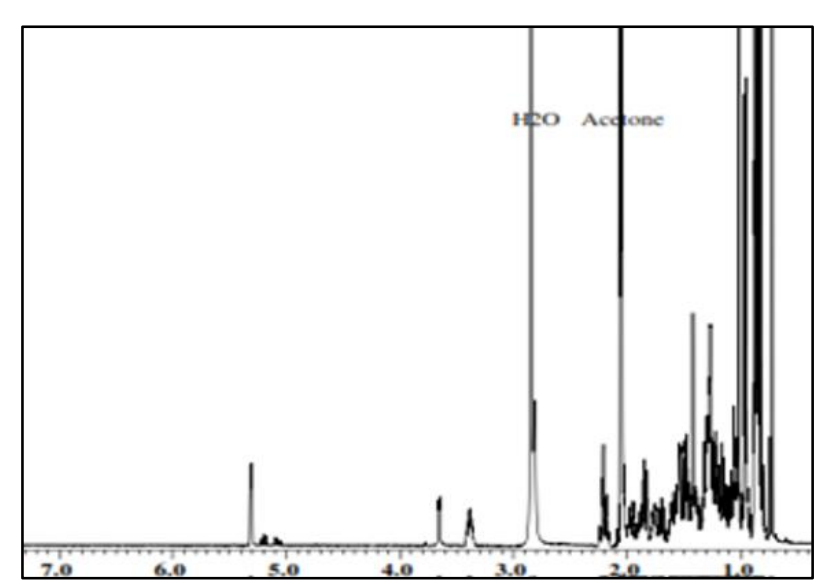

Figure 4. The Spectrum ${ }^{1} \mathrm{H}-\mathrm{NMR}$ of $\beta$-sitosterol

The ${ }^{13} \mathrm{C}-\mathrm{NMR}$ spectrum (Figure 5) shows the appearance of 29 carbon signals. The DEPT-135 spectrum (Figure 6) displays the peaks for the $\mathrm{CH}_{3}$, and $\mathrm{CH}$ while peaks that appear in the $20-40 \mathrm{ppm}$ region indicate the presence of eleven $\mathrm{CH}_{2}$ groups. Three signals that do not appear in the DEPT 135 spectrum (Figure 6) confirm the three quaternary carbons.

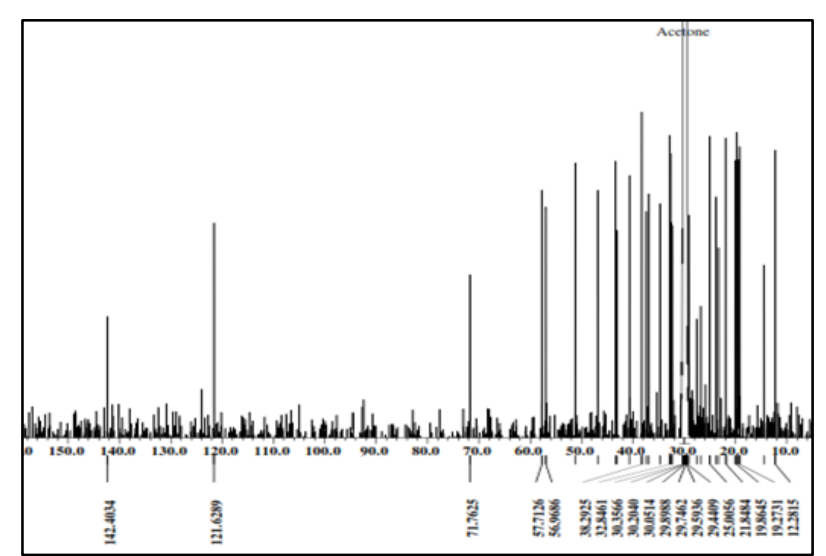

Figure 5. The ${ }^{13} \mathrm{C}-\mathrm{NMR}$ of $\beta$-sitosterol

The carbon signals at $\delta 121.61$ and $142.4 \mathrm{ppm}$ are assigned to the olefinic carbons $(\mathrm{C}=\mathrm{C})$ of $\mathrm{C}_{5}$ and $\mathrm{C}_{6}$. The $\mathrm{C}_{3}$ attached to the $\beta-\mathrm{OH}$ group at $\delta 71.76 \mathrm{ppm}$ and the signal at $\delta 12.28$ and $19.37 \mathrm{ppm}$ are assigned to the angular methyl carbons of $\mathrm{C}_{18}$ and $\mathrm{C}_{19}$, respectively. 


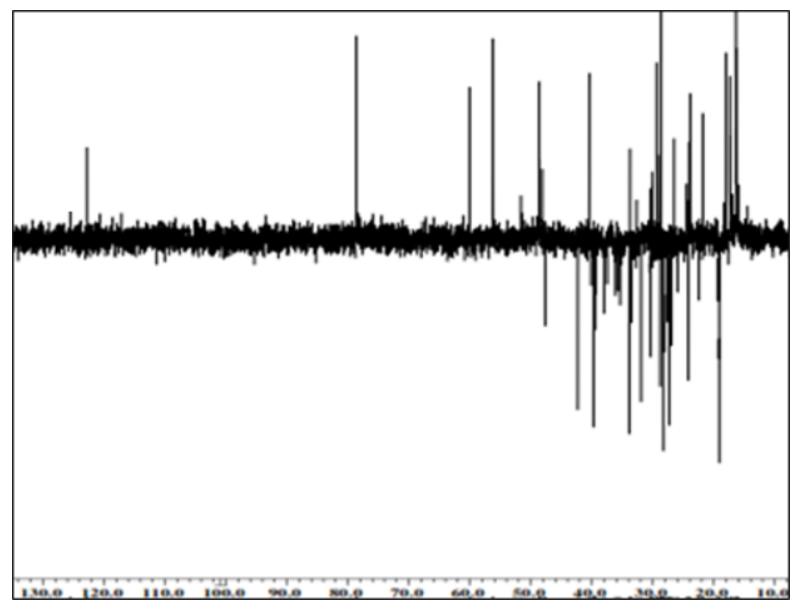

Figure 6. The DEPT 135 of $\beta$-sitosterol

The mass molecular ion peak at $m / z \quad 414$ indicates that the compound has a calculated theoretical value for $\mathrm{C}_{29} \mathrm{H}_{50} \mathrm{O}$ as shown in Figure 7. The peak at $\mathrm{m} / \mathrm{z} 301$ corresponds to [M-113] or the loss of $\left(-\mathrm{C}_{8} \mathrm{H}_{17}\right)$, the peak at $m / z 273$ resembles to [M-141] or loss of aliphatic chain $\left(-\mathrm{C}_{10} \mathrm{H}_{21}\right)$, and the peak at $m / z 396$ parallels to [M-18] or loss of hydroxy group. Based on spectroscopy analysis and comparison data from the previous report, the structure of the pure isolated compound is determined as $\beta$-sitosterol.

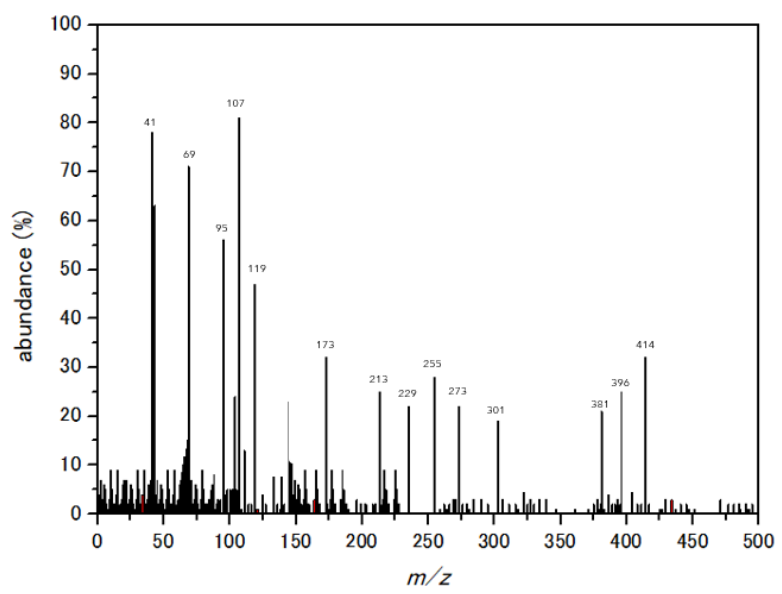

Figure 7. The GC-MS spectrum of $\beta$-sitosterol

The chemical shift data in Table 2 show that the NMR spectrum is similar to the $\beta$-sitosterol data reported by Patra et al. [27]. All the NMR data of $\beta-$ sitosterol are summarized in Table 2 and modelled in Figure 8 .

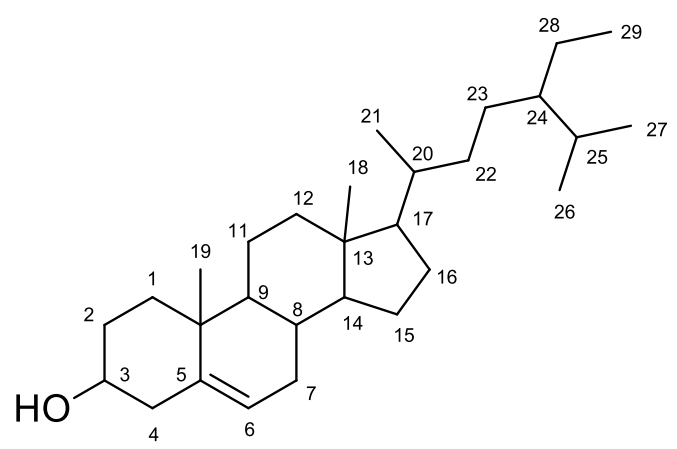

Figure 8. The structure of $\beta$-sitosterol
Table 2. The Spectrum ${ }^{1} \mathrm{H}-\mathrm{NMR},{ }^{13} \mathrm{C}-\mathrm{NMR}$, and DEPT 135 of $\beta$-sitosterol

\begin{tabular}{|c|c|c|c|c|c|c|}
\hline \multicolumn{4}{|c|}{ The pure $\beta$-sitosterol isolate } & \multicolumn{3}{|c|}{ Literature [27] } \\
\hline $\begin{array}{c}\text { No. } \\
\text { C }\end{array}$ & $\begin{array}{c}{ }^{13} \mathrm{C}- \\
\mathrm{NMR} \\
(\delta, \\
\mathrm{ppm})\end{array}$ & DEPT 135 & $\begin{array}{c}{ }^{1} \mathrm{H}-\mathrm{NMR}(\delta, \\
\text { ppm) }\end{array}$ & $\begin{array}{c}{ }^{13} \mathrm{C}- \\
\mathrm{NMR} \\
(\delta, \\
\mathrm{ppm})\end{array}$ & DEPT 135 & $\begin{array}{c}{ }^{1} \mathrm{H}-\mathrm{NMR}(\delta, \\
\text { ppm) }\end{array}$ \\
\hline 1 & 38.29 & $\mathrm{CH}_{2}$ & & 37.28 & $\mathrm{CH}_{2}$ & \\
\hline 2 & 31.69 & $\mathrm{CH}_{2}$ & $2.3(m)$ & 31.69 & $\mathrm{CH}_{2}$ & $2.31(m)$ \\
\hline 3 & 71.76 & $\mathrm{CH}-\mathrm{OH}$ & $3.52(1 \mathrm{H}, m)$ & 71.82 & $\mathrm{CH}-\mathrm{OH}$ & $3.52(1 \mathrm{H}, m)$ \\
\hline 4 & 43.41 & $\mathrm{CH}_{2}$ & $2.3(m)$ & 42.33 & $\mathrm{CH}_{2}$ & $2.31(m)$ \\
\hline 5 & 142.4 & C & & 140.7 & C & \\
\hline 6 & 121.62 & $\mathrm{CH}$ & $5.38(1 \mathrm{H}, d)$ & 121.72 & $\mathrm{CH}$ & $5.36(d)$ \\
\hline 7 & 32.68 & $\mathrm{CH}_{2}$ & 2.01 & 31.69 & $\mathrm{CH}_{2}$ & $2.08(d)$ \\
\hline 8 & 32.84 & $\mathrm{CH}$ & & 31.93 & $\mathrm{CH}$ & \\
\hline 9 & 51.26 & $\mathrm{CH}$ & & 50.17 & $\mathrm{CH}$ & \\
\hline 10 & 37.36 & $\mathrm{C}$ & & 36.52 & $\mathrm{C}$ & \\
\hline 11 & 21.84 & $\mathrm{CH}_{2}$ & & 21.1 & $\mathrm{CH}_{2}$ & \\
\hline 12 & 40.71 & $\mathrm{CH}_{2}$ & & 39.8 & $\mathrm{CH}_{2}$ & \\
\hline 13 & 43.14 & $\mathrm{C}$ & & 42.33 & $\mathrm{C}$ & \\
\hline 14 & 56.96 & $\mathrm{CH}$ & & 56.79 & $\mathrm{CH}$ & \\
\hline 15 & 23.79 & $\mathrm{CH}_{2}$ & & 24.37 & $\mathrm{CH}_{2}$ & \\
\hline 16 & 29.02 & $\mathrm{CH}_{2}$ & & 28.25 & $\mathrm{CH}_{2}$ & \\
\hline 17 & 57.71 & $\mathrm{CH}$ & & 56.09 & $\mathrm{CH}$ & \\
\hline 18 & 12.28 & $\mathrm{CH}_{3}$ & $0.68(3 \mathrm{H}, \mathrm{s})$ & 11.86 & $\mathrm{CH}_{3}$ & $0.68(3 \mathrm{H}, s)$ \\
\hline 19 & 19.27 & $\mathrm{CH}_{3}$ & & 19.4 & $\mathrm{CH}_{3}$ & \\
\hline 20 & 36.99 & $\mathrm{CH}$ & & 36.52 & $\mathrm{CH}$ & \\
\hline 21 & 19.27 & $\mathrm{CH}_{3}$ & & 18.79 & $\mathrm{CH}_{3}$ & \\
\hline 22 & 34.74 & $\mathrm{CH}_{2}$ & & 33.98 & $\mathrm{CH}_{2}$ & \\
\hline 23 & 26.77 & $\mathrm{CH}_{2}$ & & 26.14 & $\mathrm{CH}_{2}$ & \\
\hline 24 & 46.76 & $\mathrm{CH}$ & & 45.88 & $\mathrm{CH}$ & \\
\hline 25 & 29.2 & $\mathrm{CH}$ & & 28.91 & $\mathrm{CH}$ & \\
\hline 26 & 20.15 & $\mathrm{CH}_{3}$ & $0.84(3 \mathrm{H}, d)$ & 19.8 & $\mathrm{CH}_{3}$ & $0.83(3 \mathrm{H}, d)$ \\
\hline 27 & 19.11 & $\mathrm{CH}_{3}$ & $0.82(3 \mathrm{H}, d)$ & 18.79 & $\mathrm{CH}_{3}$ & $0.85(3 \mathrm{H}, d)$ \\
\hline 28 & 23.79 & $\mathrm{CH}_{2}$ & & 23.1 & $\mathrm{CH}_{2}$ & \\
\hline 29 & 12.32 & $\mathrm{CH}_{3}$ & $0.84(3 \mathrm{H}, d)$ & 11.99 & $\mathrm{CH}_{3}$ & $0.86(3 \mathrm{H}, d)$ \\
\hline
\end{tabular}

The crude extract exhibits more inhibition zones than pure isolated of $\beta$-sitosterol because the crude extract contains many other bioactive compounds that have not been identified as shown in Figure 9. Based on the zone of inhibition (ZOI) classification, according to Davis and Stout [28], the four strength that correspond to ZOI diameters: $>20 \mathrm{~mm}$ are classified as very strong inhibition, $10-20 \mathrm{~mm}$ as strong inhibition, $5-10 \mathrm{~mm}$ as moderate inhibition and $<5 \mathrm{~mm}$ is classified as no inhibition. The $\beta$-sitosterol had the potential to fight $E$. coli with moderate activity compared to the two positive controls as summarized in Table 3. 

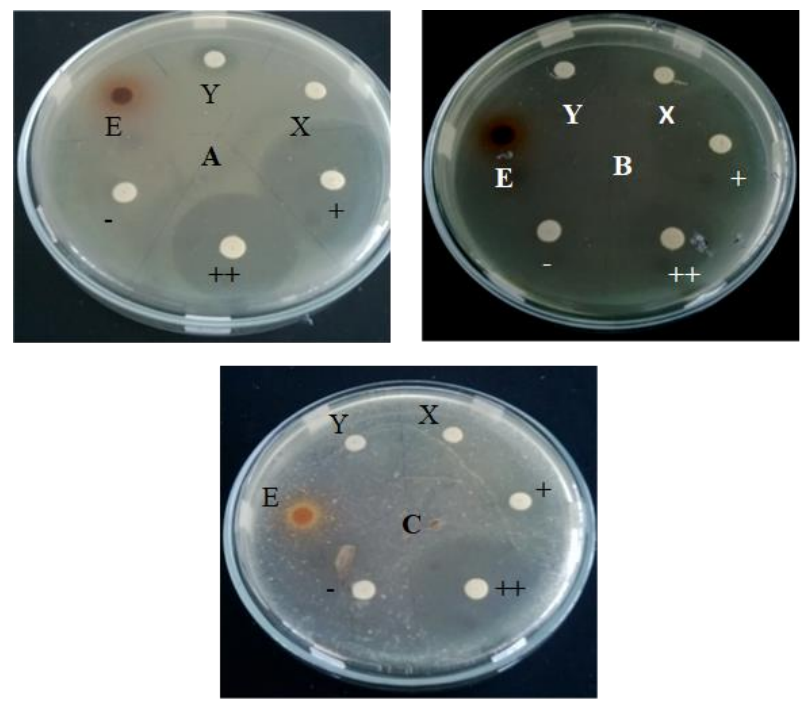

Figure 9. The Antimicrobial activity of $\beta$-sitosterol against (A) E. coli; (B) B. Subtilis and (C) A. niger; (E) Crude extract, (Y) $\beta$-sitosterol against; (X) Compound X; (+) and $(++)$ positive control; $(-)$ acetone.

Table 3. Antimicrobial activity of $\beta$-sitosterol from the root bark of $R$. apiculata.

\begin{tabular}{|c|c|c|c|c|c|}
\hline \multirow{2}{*}{ 莫 } & \multirow[b]{2}{*}{ Samples } & \multirow{2}{*}{$\begin{array}{c}\text { Concentrati } \\
\text { ons } \\
\text { (mg/mL) }\end{array}$} & \multicolumn{3}{|c|}{ Zone of inhibition in $\mathrm{mm}$} \\
\hline & & & E. coli & $\begin{array}{c}\text { B. } \\
\text { subtilis }\end{array}$ & A. niger \\
\hline $\mathrm{E}$ & $\begin{array}{l}\text { Crude } \\
\text { extract }\end{array}$ & 10 & $16 \pm 2$ & $14 \pm 1$ & $10 \pm 2$ \\
\hline $\mathrm{Y}$ & $\beta$-sitosterol & 10 & $8 \pm 2$ & - & - \\
\hline+ & $\begin{array}{c}\text { Chloramphe } \\
\text { nicol }\end{array}$ & 10 & $26 \pm 3$ & $29 \pm 2$ & $17 \pm 2$ \\
\hline++ & Clotrimazole & 10 & $21 \pm 1$ & $19 \pm 3$ & $24 \pm 4$ \\
\hline- & $\begin{array}{l}\text { Negative } \\
\text { control }\end{array}$ & 0 & - & - & - \\
\hline
\end{tabular}

Previous reports have exhibited that $\beta$-sitosterol has antibacterial activity against $S$. aureus and E. coli [29]. The $\beta$-sitosterol inhibited the growth of E. coli $(14.5 \pm$ $1.84 \mathrm{~mm})$ and $S$. aureus $(17.83 \pm 0.58 \mathrm{~mm})$ [30]. The differences in the $\beta$-sitosterol activity to generate an inhibition zone are presumably dependent on the condition of the antimicrobial assay. The different antimicrobial assay conditions have different sample solvents and microbial test concentrations [31]. The $\beta-$ sitosterol has been registered as a non-toxic and safe supplement. $\beta$-sitosterol has been registered as a nontoxic and safe supplement. It has potential bioactivities in several applications, including antibacterial activity.

\section{Conclusion}

This study reported the isolation and structure elucidation of $\beta$-sitosterol from the root bark of Bakau Minyak from Lempasing coastal, South Lampung. This study supported the use of Bakau Minyak as a traditional medicine to treat several diseases such as infections by $E$. coli. The antibacterial activity of $\beta$-sitosterol from the root bark of R. apiculata exhibited potential bioactivity to be developed as a lead compound for bacterial infections. The high potency of $\beta$-sitosterol and its analogs in treating various diseases classifies this compound as an essential drug in the future.

\section{Acknowledgment}

The authors are grateful to Biochemistry Laboratory, Universitas Lampung for technical assistance, LP3 ITERA for funding support of the GBU45 program, and LIPI-Cibinong for obtaining the NMR spectra.

\section{References}

[1] Shyamaladevi Babu, Selvaraj Jayaraman, An update on $\beta$-sitosterol: A potential herbal nutraceutical for diabetic management, Biomedicine \& Pharmacotherapy, 131, (2020), 110702 https://doi.org/10.1016/j.biopha.2020.110702

[2] J. L. Weihrauch, J. M. Gardner, Sterol content of foods of plant origin, Journal of the American Dietetic Association, 73, 1, (1978), 39-47

[3] Mesfin Medihin Ododo, Manash Kumar Choudhury, Ahmed Hussen Dekebo, Structure elucidation of $\beta-$ sitosterol with antibacterial activity from the root bark of Malva parviflora, SpringerPlus, 5, 1, (2016), 1210 https://doi.org/10.1186/s40064-016-2894-X

[4] Simin Feng, Ling Gan, Chung S. Yang, Anna B. Liu, Wenyun Lu, Ping Shao, Zhuqing Dai, Peilong Sun, Zisheng Luo, Effects of Stigmasterol and $\beta$ Sitosterol on Nonalcoholic Fatty Liver Disease in a Mouse Model: A Lipidomic Analysis, Journal of Agricultural and Food Chemistry, 66, 13, (2018), 34173425 https://doi.org/10.1021/acs.jafc.7b06146

[5] Santosh B. Dighe, B. S. Kuchekar, S. B. Wankhede, Analgesic and anti-inflammatory activity of $\beta-$ sitosterol isolated from leaves of Oxalis corniculata, International Journal of Pharmacological Research, 6, 3, (2016), 109-113

[6] Ramalingam Sharmila, Ganapathy Sindhu, Evaluate the Antigenotoxicity and anticancer role of $\beta$ Sitosterol by determining oxidative DNA damage and the expression of phosphorylated mitogenactivated protein Kinases', C-fos, C-Jun, and endothelial growth factor receptor, Pharmacognosy magazine, 13, 49, (2017), 95-101

[7] Lorenzo Fraile, Elisa Crisci, Lorena Córdoba, María A. Navarro, Jesús Osada, María Montoya, Immunomodulatory properties of Beta-sitosterol in pig immune responses, International Immunopharmacology, 13, 3, (2012), 316-321 https://doi.org/10.1016/j.intimp.2012.04.017

[8] Chuanxun Yuan, Xueru Zhang, Xue Long, Jing Jin, Risheng Jin, Effect of $\beta$-sitosterol selfmicroemulsion and $\beta$-sitosterol ester with linoleic acid on lipid-lowering in hyperlipidemic mice, Lipids in Health and Disease, 18, 1, (2019), 157 https://doi.org/10.1186/s12944-019-1096-2

[9] Shyamaladevi Babu, Madhan Krishnan, Ponnulakshmi Rajagopal, Vijayalakshmi Periyasamy, Vishnupriya Veeraraghavan, Ramajayam Govindan, Selvaraj Jayaraman, Betasitosterol attenuates insulin resistance in adipose tissue via IRS-1/Akt mediated insulin signaling in high fat diet and sucrose induced type-2 diabetic rats, European Journal of Pharmacology, 873, (2020), 173004 https://doi.org/10.1016/j.ejphar.2020.173004

[10] Yong Joo Park, In Jae Bang, Mi Ho Jeong, Ha Ryong Kim, Da Eun Lee, Jong Hwan Kwak, Kyu Hyuck 
Chung, Effects of $\beta$-Sitosterol from Corn Silk on TGF- $\beta$ 1-Induced Epithelial-Mesenchymal Transition in Lung Alveolar Epithelial Cells, Journal of Agricultural and Food Chemistry, 67, 35, (2019), 9789-9795

https://doi.org/10.1021/acs.jafc.9b02730

[11] Hari Gajula, Vadlapudi Kumar, Poornima D. Vijendra, J. Rajashekar, Torankumar Sannabommaji, Giridhara Basappa, Chapter 5 Secondary metabolites from mangrove plants and their biological activities, in: J.K. Patra, R.R. Mishra, H. Thatoi (Eds.) Biotechnological Utilization of Mangrove Resources, Academic Press, 2020, https://doi.org/10.1016/B978-0-12-819532-1.00005-6

[12] R. Ponnulakshmi, B. Shyamaladevi, P. Vijayalakshmi, J. Selvaraj, In silico and in vivo analysis to identify the antidiabetic activity of beta sitosterol in adipose tissue of high fat diet and sucrose induced type- 2 diabetic experimental rats, Toxicology Mechanisms and Methods, 29, 4, (2019), 276-290

https://doi.org/10.1080/15376516.2018.1545815

[13] Rogelio Paniagua-Pérez, Gabriela FloresMondragón, Celia Reyes-Legorreta, Brígida Herrera-López, Isabel Cervantes-Hernández, Osiris Madrigal-Santillán, José Antonio MoralesGonzález, Isela Álvarez-González, Eduardo Madrigal-Bujaidar, Evaluation of the antiinflammatory capacity of beta-sitosterol in rodent assays, African Journal of Traditional, Complementary and Alternative Medicines, 14, 1, (2017), 123-130 https://doi.org/10.21010/ajtcam.v14i1.13

[14] Food and Drug Administration, in: F. Register (Ed.) 2011-20406, Federal Register, Washington DC, US, 2011, p. 49707-49708

[15] Authority European Food Safety, Plant Sterols and Blood Cholesterol - Scientific substantiation of a health claim related to plant sterols and lower/reduced blood cholesterol and reduced risk of (coronary) heart disease pursuant to Article 14 of Regulation (EC) No 1924/2006, EFSA Journal, 6, 8, (2008), 781 https://doi.org/10.2903/j.efsa.2008.781

[16] Jun Wu, Qiang Xiao, Jing Xu, Min-Yi Li, Jian-Yu Pan, Mei-hua Yang, Natural products from true mangrove flora: source, chemistry and bioactivities, Natural Product Reports, 25, 5, (2008), 955-981 http://dx.doi.org/10.1039/B807365A

[17] V. Sachithanandam, P. Lalitha, A. Parthiban, T. Mageswaran, K. Manmadhan, R. Sridhar, A Review on Antidiabetic Properties of Indian Mangrove Plants with Reference to Island Ecosystem, Evidence-Based Complementary and Alternative Medicine, 2019, (2019), 4305148 https://doi.org/10.1155/2019/4305148

[18] Dioxelis Lopez, Lilia Cherigo, Alejandro de Sedas, Carmenza Spadafora, Evaluation of antiparasitic, anticancer, antimicrobial and hypoglycemic properties of organic extracts from Panamanian mangrove plants, Asian Pacific Journal of Tropical Medicine, 11, 1, (2018), 32

https://doi.org/10.4103/1995-7645.223531

[19] Dini P. Sari, Mohammad Basyuni, Poppy A. Z. Hasibuan, Sumardi Sumardi, Arif Nuryawan, Ridha Wati, Cytotoxic and antiproliferative activity of polyisoprenoids in seventeen mangroves species against WiDr colon cancer cells, Asian Pacific Journal of Cancer Prevention, 19, 12, (2018), 3393-3400 https://dx.doi.org/10.31557/APJCP.2018.19.12.3393
[20] H. N. Thatoi, J. K. Patra, S. K. Das, Free radical scavenging and antioxidant potential of mangrove plants: a review, Acta Physiologiae Plantarum, 36, 3 , (2014), 561-579 https://doi.org/10.1007/s11738-013-1438-z

[21] Alik Kandhita Febriani, Ismiyarto Ismiyarto, Khairul Anam, Total Phenolic and Coumarin Content, Antioxidant Activity of Leaves, Fruits, and Stem Barks of Grey Mangrove (Avicennia marina), Jurnal Kimia Sains dan Aplikasi, 23, 2, (2020), 34-38 https://doi.org/10.14710/jksa.23.2.34-38

[22] Shadia M. Abdel-Aziz, Foukia E. Mouafi, Yomna A. Moustafa, Nayera A. M. Abdelwahed, Medicinal Importance of Mangrove Plants, in: N. Garg, S.M. Abdel-Aziz, A. Aeron (Eds.) Microbes in Food and Health, Springer International Publishing, Cham, 2016, https://doi.org/10.1007/978-3-319-25277-3_5

[23] Jayanta Kumar Patra, Hrudaya Nath Thatoi, Metabolic diversity and bioactivity screening of mangrove plants: a review, Acta Physiologiae Plantarum, 33, 4, (2011), 1051-1061 https://doi.org/10.1007/s11738-010-0667-7

[24] Ravindran, K. Venkatesan, Veluchamy Balakrishnan, K. P. Balasubramanian, Ethnomedicinal studies of Pichavaram mangroves of East coast, Tamil Nadu, Indian Journal of Traditional Knowledge, 4, (2005), 409-411

[25] Rahmat Kurniawan, Abstrak Isolasi, Identifikasi, dan Uji Bioaktivitas Senyawa Stigmast-5-En-3 $\beta-01$ (B-Sitosterol) Dari Kulit Akar Bakau Minyak (Rhizophora apiculata) undergraduate thesis, Department of Chemistry, Universitas Lampung, Bandar Lampung, 2014

[26] Mounyr Balouiri, Moulay Sadiki, Saad Koraichi Ibnsouda, Methods for in vitro evaluating antimicrobial activity: A review, Journal of Pharmaceutical Analysis, 6, 2, (2016), 71-79 https://doi.org/10.1016/j.jpha.2015.11.005

[27] Arjun Patra, S Jha, P. N. Murthy, Manik, A. Sharone, Isolation and characterization of stigmast-5-en$3 \beta-o l$ ( $\beta$-sitosterol) from the leaves of Hygrophila spinosa T. Anders, International Journal of Pharma Sciences and Research, 1, 2, (2010), 95-100

[28] W. W. Davis, T. R. Stout, Disc Plate Method of Microbiological Antibiotic Assay, Applied Microbiology, 22, 4, (1971), 659-665

[29] Amit Sen, Poonam Dhavan, Kshitiz Kumar Shukla, Sanjay Singh, G Tejovathi, Analysis of IR, NMR and antimicrobial activity of $\beta$-sitosterol isolated from Momordica charantia, Science Secure Journal of Biotechnology, 1, 1, (2012), 9-13

[30] J. H. Hoskeri, V. Krishna, S. Jignesh, S. T. Sanjay, A. Roshan, S. Vijay, In-Silico drug designing using $\beta-$ sitosterol isolated from Flaveria trinervia against peptide deformylase protein to hypothesize bactericidal effect, International Journal of Pharmacy and Pharmaceutical Sciences, 4, 2, (2012), 192-196

[31] Andres F. Zuluaga, Maria Agudelo, Carlos A. Rodriguez, Omar Vesga, Application of microbiological assay to determine pharmaceutical equivalence of generic intravenous antibiotics, $B M C$ Clinical Pharmacology, 9, 1, (2009), 1 https://doi.org/10.1186/1472-6904-9-1 